\title{
Stromal expression of CD10 in breast carcinoma and its correlation with clinicopathological parameters
}

\author{
Ashish Nitin Dhande, Siddhi Gaurish Sinai Khandeparkar, Avinash R. Joshi, Maithili Mandar Kulkarni, Nidhi Pandya, \\ Neelam Mohanapure, Aakriti Aggarwal, Gargi Patil
}

\begin{abstract}
Introduction: Breast cancer is the foremost cause of death in women worldwide with more than one million cases occurring annually. Aim: This study was conducted to study the stromal CDIO expression in breast carcinomas (BCa) and its correlation with various prognostic factors such as tumor size, histological grade, lymph node status, estrogen receptor (ER), progesterone receptor (PR), HER2neu, and Ki67 status. Materials and Methods: Sixty cases of BCa diagnosed between 2013 and 2015 were included in the study. Stromal expression of CDIO was studied on entire section of selected BCa blocks for all cases. A technique of manual tissue microarray was employed for the analysis of expression of immunohistochemical markers ER, PR, and HER2/Neu and Ki67 in all cases. Results were subjected to statistical analysis. Results: Stromal CD I 0 positivity was seen in $78.3 \%$ cases, out of which $53.3 \%$ of cases were strongly positive, and $25.0 \%$ cases were weakly positive. Positivity for ER, PR, HER2, and Ki67 was $31.7 \%, 33.3 \%, 65 \%$, and $75 \%$, respectively. Stromal expression of CDIO was found to be significantly associated with increasing tumor grade, lymph node status, HER2neu positivity, ER negativity, and Ki67 positivity. CDIO stromal expression was seen mainly in PR negative BCa cases; however, it was statistically insignificant. It was noted that CDIO stromal positivity increased with increasing grade. Conclusion: CDIO can be used as an independent prognostic marker and should be included in routine histopathology report. CDIO could act as a potential target for newer drug development.
\end{abstract}

Key words: Breast cancer, CDI0, estrogen receptor, HER2neu, Ki67, progesterone receptor

\section{Introduction}

Breast cancer (BC), a major health burden both in the developed and developing countries, is the foremost cause of death in women worldwide with more than one million cases occurring annually. ${ }^{[1,2]}$

There has been sufficient evidence in the literature that supports tissue microenvironment as having a vital role in controlling cell survival, proliferation, migration, polarization, and differentiation. ${ }^{[3]}$ The prognostic role of novel stromal marker such as CD 10 is less studied in literature. CD10 or common acute lymphoblastic antigen, a zinc-dependent metalloproteinase, is commonly expressed in bone marrow lymphoid stem cells, pro-B lymphoblasts, mature neutrophils, various lymphoma subtypes, renal cell carcinoma, and endometrial stromal sarcoma. ${ }^{[4]}$ Stromal CD10 expression is known to be associated with biological aggressiveness in various epithelial malignancies ${ }^{[5-7]}$ and phyllodes tumor. ${ }^{[8]}$

The present study was conducted to study the stromal CD10 expression in breast carcinomas (BCa) cases.

\section{Materials and Methods}

This cross-sectional study was conducted in the Department of Pathology in Smt. Kashibai Navale Medical College and General Hospital, Pune, Maharashtra, India. Ethical Clearance was obtained from Institute's Ethical Committee. Sixty cases of BCa cases operated on and diagnosed from 2013 to 2015 were included in the study. The available data for all the patients as regards with age, the location of tumor, grade, stage, and lymph node status was collected from the records of histopathology section of the department of pathology.

All the slides were evaluated by two senior histopathologists. The modified Bloom-Richardson system of cancer grading system was used in this study. Tumor node metastasis classification

\begin{tabular}{|c|}
\hline Access this article online \\
\hline 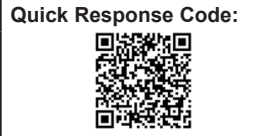 \\
\hline Website: www.sajc.org \\
\hline DOI: 10.4103/sajc.sajc_56_18 \\
\hline
\end{tabular}

Department of Pathology, Smt. Kashibai Navale Medical College and General Hospital, Pune, Maharashtra, India Correspondence to: Dr. Siddhi Gaurish Sinai Khandeparkar,

E-mail: siddhigsk@yahoo.co.in and staging of the cases was done as per the American Joint Committee on Cancer guidelines. ${ }^{[9]}$ The most suitable tissue block of BCa cases was selected for immunohistochemical (IHC) evaluation. Stromal expression of CD10 was studied on entire section of selected BCa blocks for all cases. Antigen retrieval was done using Citrate Buffer Antigen Retrieval Protocol. The pressure cooker was used as heating source. A technique of manual tissue microarray was employed for the study of ER, $\mathrm{PR}$, and HER2/Neu, Ki67 in all cases with one tissue core taken from each selected BCa block. ${ }^{[10]}$

The primary antibodies used were Anti-Human CD10 (Clone 56C6, Dako), estrogen receptor (ER) (Clone 6F 11, Novacastra), progesterone receptor (PR) (Clone PGR312, Novacastra), HER2/Neu (Clone CB11, Novacastra), Ki-67 (Clone MM1, Novacastra). Negative control (without adding primary antibody) was included in all batches. Periductal stromal cells and nonneoplastic myoepithelial cells in fibroadenoma were used as positive control for CD10 expression. The section from endometrial tissue was used as positive control for ER and PR. The section from BC, which previously showed unequivocal strong immunoreactivity for HER2/neu, was used as positive control for HER2/neu. Section from skin was used as positive control for Ki67. Sections were examined under high-power field to observe the immunoreactivity.

CD10 expression in the tumor stroma (both in stromal cells and extracellular matrix) was assessed and scored as CD10 positive when more than $10 \%$ of the stromal cells showed positivity. ${ }^{[6]}$ CD10 positive tumors were further classified as CD10 weakly positive when $10 \%-30 \%$ of stromal cells positive and CD10 strongly positive when more than $30 \%$ stromal cells were positive. ${ }^{[7]}$

This is an open access journal, and articles are distributed under the terms of the Creative Commons Attribution-NonCommercial-ShareAlike 4.0 License, which allows others to remix, tweak, and build upon the work non-commercially, as long as appropriate credit is given and the new creations are licensed under the identical terms.

For reprints contact: reprints@ medknow.com

How to cite this article: Dhande AN, Sinai Khandeparkar SG, Joshi AR, Kulkarni MM, Pandya N, Mohanapure N, et al. Stromal expression of CD 10 in breast carcinoma and its correlation with clinicopathological parameters. South Asian J Cancer 2019;8:18-21. 
Allred score was used to evaluate the ER and PR, and a score of 3-8 was considered positive. Immunoreactivity for ER and PR was assessed by estimating the percentage of tumor cells showing nuclear staining. More than $10 \%$ of the tumor cells showing immunoreactivity were considered as positive. ${ }^{[1]]}$ HER2 staining was scored according to the American Society of Clinical Oncology/College of American Pathologists guidelines. Moderate-to-strong complete membrane staining of $10 \%$ or more of the tumor cells was considered to be positive $(2+\text { and } 3+)^{[12]} \mathrm{Ki} 67$ Labeling index of equal to or more than $10 \%$ was considered to be positive. ${ }^{[13]}$

The Primer of Biostatistics 7.0 program was used for the calculation of interrelationships between the analyzed stromal expression of CD10 and clinicopathological variables by Pearson's Chi-square test. Quantitative data were presented with the help of mean. Qualitative data were presented with the help of frequency and percentage table. The results were considered to be statistically significant when the $P$ value was $<0.05$ and highly statistically significant when $P<0.01$.

\section{Results}

Out of the 60 cases studied, $47(78.3 \%)$ cases showed stromal CD10 positivity, out of which $32(53.3 \%)$ cases were strongly positive whereas $15(25.0 \%)$ cases were weakly positive [Figure 1]. This included two cases of IDC with DCIS, one of them showing strong and other weak stromal CD10 positivity. 13/60 (21.7\%) cases were CD10 negative. All medullary carcinoma cases $(5 / 5)$ showed stromal CD10 positivity, $4 / 5(80 \%)$ were strongly positive whereas $1 / 5(20 \%)$ was weakly positive. Single case of papillary adenocarcinoma showed strong stromal CD10 positivity. Cases of mucinous carcinoma (2/2) and secretory carcinoma $(1 / 1)$ of breast were CD10 negative.

Stromal expression of CD10 in BCa cases [Table 1] and its correlation with various clinicopathological features is shown in [Table 2]. Stromal expression of CD10 showed highly statistically significant correlation with increasing tumor grade $\left(\chi^{2}=12.673 ; P<0.05\right)$ and lymph node status $\left(\chi^{2}=7.672 ; P<0.01\right)$.

Stromal CD10 positivity was significantly associated with ER negativity $\left(\chi^{2}=5.195 ; P<0.05\right)$ and Ki67 positivity $\left(\chi^{2}=5.532 ; P<0.05\right)$. Stromal expression of CD10 demonstrated highly statistically significant association with HER2neu positivity $\left(\chi^{2}=6.735 ; P<0.01\right)$. CD10 stromal expression was seen mainly in $\mathrm{PR}$ negative $\mathrm{BCa}$ cases $\left(\chi^{2}=0.601 ; P=0.438\right)$ and $\mathrm{BCa}$ cases showing

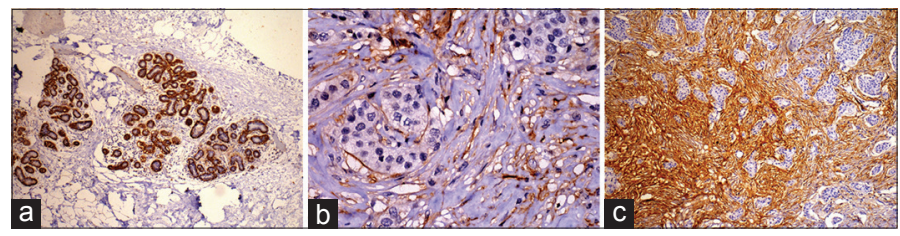

Figure 1: (a) CD 10 strong positivity in myoepithelial cells serving as built-in control ( $\times 100)$, (b) CD 10 weak stromal positivity in invasive ductal carcinoma $(\times 400)$ and (c) CD 10 strong stromal positivity in invasive ductal carcinoma $(\times 100)$ lymphovascular invasion $\left(\chi^{2}=0.006 ; P=0.938\right)$; however, it was statistically insignificant. With increasing tumor stage, the positivity of stromal CD10 expression also increased but was statistically insignificant $\left(\chi^{2}=3.709 ; P=0.156\right)$. No association was seen between CD10 stromal expression and age, menopausal status, and tumor size.

\section{Discussion}

Although breast cancer is an epithelial malignancy arising in the epithelial cells of the terminal ductal lobular unit, stromal microenvironment plays an important role in breast cancer evolution and metastasis. ${ }^{[3]}$ The interaction between normal epithelial cells and stromal cells is modified by several factors secreted by the tumor cells themselves or by stromal cells under the influence of tumor cells. ${ }^{[3]}$ One such important factor is the matrix metalloproteinase (MMP). MMP plays an important role in tumor progression and in defining the role of stromal microenvironment in tumor invasion and metastasis. ${ }^{[14]}$ CD10 is a cell surface zinc-dependent metalloproteinase that cleaves the protein components of extracellular matrix and thereby plays a pivotal role in tissue remodeling. ${ }^{[4]}$

In the present study, $78.3 \%$ of the $\mathrm{BCa}$ cases showed stromal CD10 positivity out of which $25.0 \%$ were weakly positive whereas $53.3 \%$ were strongly positive. Some studies have reported up to $80 \%$ CD10 positivity, while others have shown slight to moderate variation in CD10 expression [Table 3]. $\cdot^{[4,7]}$

Most of the tumors in the present study were of higher stage and grade. In our study, stromal expression of CD10 increased from Grade 1 to Grade 3 BCa cases. There was highly statistically significant association between CD10 stromal expression and tumor grade similar to other studies in literature. ${ }^{[3,6,7]}$

In present study, stromal CD10 positivity was highest in Stage $3(40 \%)$ followed by Stage $2(36.6 \%)$. Although CD10 positivity increased with increasing stage of $\mathrm{BCa}$, there was no statistically significant association between stromal CD10 expression and stage of tumor. Similar findings were observed in studies in literature, ${ }^{[3,6]}$ however, highly statistically significant association between stromal CD10 expression and tumor stage is also documented. ${ }^{[15]}$

In our study, there was no statistically significant association between CD10 expression and tumor size as observed in other studies. ${ }^{[3,6,7]}$ No statistically significant association was noticed between stromal CD10 expression and LVI. However, it was seen that CD10 positive tumors showed higher frequency of LVI. No other study was found in literature correlating CD10 expression with LVI. 90\% BCa cases with lymph node metastasis in our study showed CD10 positivity, and this was highly statistically significant. Similar findings were seen in literature. ${ }^{[6]}$

Makretsov et al. showed statistically significant correlation between strong CD10 staining and ER negativity. ${ }^{[7]}$ Similarly, in our study, CD10 was found to have statistically significant negative correlation with ER. Makretsov et al. found no

Table 1: Distribution of cases according to the stromal expression of CD10

\begin{tabular}{|c|c|c|c|c|}
\hline \multirow[t]{2}{*}{ IHC marker } & \multicolumn{3}{|c|}{ CD10 positive $(n=47 ; 78.3 \%)$} & \multirow[t]{2}{*}{ CD10 negative, $n(\%)$} \\
\hline & Weakly positive, $n(\%)$ & Strongly positive, $n(\%)$ & Total CD10 positive, $n(\%)$ & \\
\hline CD10 & $15(25.0)$ & $32(53.3)$ & $47(78.3)$ & $13(21.7)$ \\
\hline
\end{tabular}


Table 2: Stromal expression of CD10 and its correlation with clinicopathological parameters of breast carcinoma

\begin{tabular}{|c|c|c|c|}
\hline \multirow[t]{2}{*}{ Variables $(n)$} & \multicolumn{2}{|c|}{ Stromal expression of CD10 } & \multirow{2}{*}{$\begin{array}{c}\chi^{2} \text { and } \\
P\end{array}$} \\
\hline & $\begin{array}{l}\text { Number of cases } \\
\text { showing positivity } \\
(\%),(47 ; 78.3 \%)\end{array}$ & $\begin{array}{c}\text { Number of cases } \\
\text { showing negativity } \\
(\%),(13 ; 21.7 \%)\end{array}$ & \\
\hline \multicolumn{4}{|c|}{ (2) } \\
\hline$\leq 50$ years $(29)$ & $23(38.3)$ & $6(10.0)$ & \multirow{2}{*}{$\begin{array}{c}0.018 \\
0.892\end{array}$} \\
\hline$>50$ years $(31)$ & $24(40.0)$ & $7(11.7)$ & \\
\hline \multicolumn{4}{|l|}{ Menopausal status } \\
\hline $\begin{array}{l}\text { Premenopausal } \\
\text { (15) }\end{array}$ & $12(20.0)$ & $3(5.0)$ & \multirow[t]{2}{*}{$\begin{array}{c}0.033 \\
0.856\end{array}$} \\
\hline $\begin{array}{l}\text { Postmenopausal } \\
\text { (45) }\end{array}$ & $35(58.3)$ & $10(16.7)$ & \\
\hline \multicolumn{4}{|l|}{$\begin{array}{l}\text { Histologic tumor } \\
\text { grade }\end{array}$} \\
\hline $1(9)$ & $3(5.0)$ & $6(10.0)$ & \multirow{3}{*}{$\begin{array}{c}12.673 \\
<0.01\end{array}$} \\
\hline $2(24)$ & $21(35.0)$ & $3(5.0)$ & \\
\hline $3(27)$ & $23(38.3)$ & $4(6.7)$ & \\
\hline \multicolumn{4}{|l|}{$\begin{array}{l}\text { Lymphovascular } \\
\text { invasion }\end{array}$} \\
\hline Present (48) & $38(63.3)$ & $10(16.7)$ & \multirow{2}{*}{$\begin{array}{l}0.006 \\
0.938\end{array}$} \\
\hline Absent (12) & $9(15.0)$ & $3(5.0)$ & \\
\hline \multicolumn{4}{|l|}{ Lymph node status } \\
\hline Positive (40) & $36(60.0)$ & $4(6.7)$ & \multirow{2}{*}{$\begin{array}{l}7.672 \\
<0.01\end{array}$} \\
\hline Negative (20) & $11(18.3)$ & $9(15.0)$ & \\
\hline \multicolumn{4}{|l|}{ Tumor size } \\
\hline $\mathrm{T} 1(5)$ & $4(6.7)$ & $1(1.7)$ & \multirow{4}{*}{$\begin{array}{l}1.585 \\
0.908\end{array}$} \\
\hline T2 (34) & $27(45.0)$ & $7(11.6)$ & \\
\hline T3 (12) & $8(13.3)$ & $4(6.7)$ & \\
\hline T4 (9) & $8(13.3)$ & $1(1.7)$ & \\
\hline \multicolumn{4}{|l|}{ Stage } \\
\hline $1(2)$ & $1(1.7)$ & $1(1.7)$ & \multirow{3}{*}{$\begin{array}{c}3.709 \\
0.156\end{array}$} \\
\hline $2(31)$ & $22(36.6)$ & $9(15.0)$ & \\
\hline $3(27)$ & $24(40.0)$ & $3(5.0)$ & \\
\hline \multicolumn{4}{|l|}{ ER } \\
\hline Positive (19) & $11(18.4)$ & $8(13.3)$ & \multirow{2}{*}{$\begin{array}{l}5.195 \\
<0.05\end{array}$} \\
\hline Negative (41) & $36(60.0)$ & $5(8.3)$ & \\
\hline \multicolumn{4}{|l|}{$\mathrm{PR}$} \\
\hline Positive (20) & $14(23.3)$ & $6(10.0)$ & \multirow{2}{*}{$\begin{array}{c}0.601 \\
0.438\end{array}$} \\
\hline Negative (40) & $33(55.0)$ & $7(11.7)$ & \\
\hline \multicolumn{4}{|l|}{ Her2/neu } \\
\hline Positive (39) & $35(58.3)$ & $4(6.7)$ & \multirow{2}{*}{$\begin{array}{l}6.735 \\
<0.01\end{array}$} \\
\hline Negative (21) & $12(20.0)$ & $9(15.0)$ & \\
\hline \multicolumn{4}{|l|}{ Ki67 } \\
\hline Positive (45) & $39(65)$ & $6(10.0)$ & \multirow{2}{*}{$\begin{array}{l}5.532 \\
<0.05\end{array}$} \\
\hline Negative (15) & $8(13.3)$ & $7(11.7)$ & \\
\hline
\end{tabular}

statistical significance between stromal CD10 expression and PR status. ${ }^{[6]}$ This is in accordance with our study, where CD10 was found to have good negative correlation with PR, however, it was not statistically significant. A highly statistically significant correlation was found between stromal CD10 positivity and HER2/neu expression consistent with studies done by Puri et al..$^{[4]}$ and Jana et al. ${ }^{[3]}$ On the contrary, Makretsov et al. ${ }^{[7]}$ did not find any statistically significant association between CD10 and HER2/neu expression. In our study, we found a statistically significant correlation between stromal CD10 positivity and Ki67 expression as documented by Puri et al. ${ }^{[4]}$

Stromal CD10 expression in $\mathrm{BCa}$ cases in the present study was seen to be associated with traditional prognostic markers of $\mathrm{BCa}$. Stromal CD10 expression was maximum in $\mathrm{BCa}$
Table 3: Percentage positivity of stromal expression of CD10 in other studies

\begin{tabular}{|c|c|c|c|c|}
\hline \multirow{2}{*}{$\begin{array}{l}\text { Study } \\
\text { (first author name) }\end{array}$} & \multirow{2}{*}{$\begin{array}{l}\text { Number } \\
\text { of cases }\end{array}$} & \multicolumn{3}{|c|}{ CD10 positive (\%) } \\
\hline & & $\begin{array}{l}\text { Weakly } \\
\text { positive }\end{array}$ & $\begin{array}{c}\begin{array}{c}\text { Strongly } \\
\text { positive }\end{array} \\
\end{array}$ & $\begin{array}{c}\text { Total CD10 } \\
\text { positive }\end{array}$ \\
\hline Iwaya et al. ${ }^{[6]}$ & 110 & - & - & 18 \\
\hline Makretsov et al..$^{[7]}$ & 258 & 40 & 39 & 79 \\
\hline Puri V et $a l^{[4]}$ & 50 & 32 & 48 & 80 \\
\hline Jana SH et al. ${ }^{[3]}$ & 70 & - & - & 48.6 \\
\hline Kim HS et al..$^{[15]}$ & 101 & - & - & 49.5 \\
\hline $\begin{array}{l}\text { Taghizadeh-Kermani A } \\
\text { et al. }{ }^{[7]}\end{array}$ & 100 & 36 & 28 & 64 \\
\hline Present study (\%) & 100 & 25.0 & 53.3 & 78.3 \\
\hline Present study $(n)$ & 60 & $15 / 60$ & $32 / 60$ & $47 / 60$ \\
\hline
\end{tabular}

cases with higher tumor grade and tumor stage, lymph node metastasis, ER and PR negativity, HER2/neu positivity, and Ki67 expression. This signifies its association with aggressive tumor behavior indicating that $\mathrm{CD} 10$ can be used as independent marker of poor prognosis which can be used as a target for developing novel therapies.

CD10 immunoexpression has its role in drug designing where $\mathrm{BCa}$ treatment no longer depends on designing drugs directed against the cancer epithelial cells, but drugs that can have a better delivery system, with maximum efficacy, least toxicity and that can modify the tumor microenvironment/ stroma. This has led to the development of peptide pro-drugs cleavable by peptidases present in the tumor environment. CD10, being a metalloprotease, is capable of cleaving CPI-0004Na and related peptide prodrugs, such as N-succinyl-alanyl-L-isoleucyl-L-alanyl-Lleucyl-Dox. This proteolytic cleavage generates leucyl-Dox, which is capable of entering cells and generating intracellular Dox, with a higher potency than Dox alone. Cytotoxicity of CPI-0004Na is inhibited by phosphoramidon, a known inhibitor of CD10 enzymatic activity. ${ }^{[3]}$ Therefore, routine staining of CD10 could help in deciding the line of treatment for $\mathrm{BCa}$ cases.

\section{Limitations}

TMA technique was used for ER, PR, Her2, and Ki67. Whole sections were not used for their IHC evaluation. However, utmost care was taken to sample the most representative area from the original whole section blocks for TMA. HER2 was assessed only by IHC. Evaluation by FISH was not available especially for the equivocal cases with HER2 expression $2+$. Follow-up time for the patients was limited.

\section{Conclusion}

Stromal expression of CD10 was significantly associated with higher tumor grade, lymph node metastasis, HER2neu positivity, ER negativity, and Ki67 positivity. CD10 can be used as an independent prognostic marker and should be included in routine histopathology report. CD10 could act as a potential target for newer drug development.

Financial support and sponsorship

Nil.

\section{Conflicts of interest}

There are no conflicts of interest.

\section{References}

1. Rosai J. Breast. In: Rosai J, editor. Rosai and Ackerman's Surgical Pathology. 10 ${ }^{\text {th }}$ ed. Vol. 2. New Delhi: Elsevier; 2012. p. 1659-770.

South Asian Journal of Cancer • Volume 8 •Issue 1 - January-March 2019 
2. Ellis IO, Schnitt SJ, Sastre-Garau X, Bussolati G, Tavassoli FA, Eusebi V, et al. Invasive breast carcinoma. In: Tavassoli FA, Devilee P, editors. World Health Organization Classification of Tumours; Pathology and Genetics Tumours of the Breast and Female Genital Organs. Lyon: IARC press; 2003. p. 13-23.

3. Jana SH, Jha BM, Patel C, Jana D, Agarwal A. CD10-a new prognostic stromal marker in breast carcinoma, its utility, limitations and role in breast cancer pathogenesis. Indian J Pathol Microbiol 2014;57:530-6.

4. Puri V, Jain M, Thomas S. Stromal expression of CD 10 in invasive breast carcinoma and its correlation with ER, PR, HER2-neu, and Ki67. Int J Breast Cancer 2011;2011:437957.

5. Huang WB, Zhou XJ, Chen JY, Zhang LH, Meng K, Ma HH, et al. CD 10-positive stromal cells in gastric carcinoma: Correlation with invasion and metastasis. Jpn J Clin Oncol 2005;35:245-50.

6. Iwaya K, Ogawa H, Izumi M, Kuroda M, Mukai K. Stromal expression of CD10 in invasive breast carcinoma: A new predictor of clinical outcome. Virchows Arch 2002;440:589-93.

7. Makretsov NA, Hayes M, Carter BA, Dabiri S, Gilks CB, Huntsman DG, et al. Stromal CD 10 expression in invasive breast carcinoma correlates with poor prognosis, estrogen receptor negativity, and high grade. Mod Pathol 2007;20:84-9.

8. Kulkarni MM, Khandeparkar SG, Joshi AR, Kothikar V, Nasare A, Patil S, et al. Role of CD10 immunoexpression in grading phyllodes tumour of the breast. J Clin Diagn Res 2017;11:EC 14-6.

9. Lakhani SR, Ellis IO, Schnitt SJ, Tan PH, van de Vijver MJ. World Health Organization Classification of Tumours of the Breast. $4^{\text {th }}$ ed. Lyon: IARC; 2012. p. 8-108, 152.

10. Pathak GS, Deshmukh SD, Ashturkar AV. Construction of tissue arrays without prefabricated recipient paraffin block experience of a novel technique in resource poor settings. Indian J Pathol Microbiol 2011;54:654-5.

11. Collins LC, Botero ML, Schnitt SJ. Bimodal frequency distribution of estrogen receptor immunohistochemical staining results in breast cancer: An analysis of 825 cases. Am J Clin Pathol 2005;123:16-20.

12. Gutierrez C, Schiff R. HER2: Biology, detection, and clinical implications. Arch Pathol Lab Med 2011;135:55-62.

13. Tawfik K, Kimler BF, Davis MK, Fan F, Tawfik O. Ki-67 expression in axillary lymph node metastases in breast cancer is prognostically significant. Hum Pathol 2013;44:39-46.

14. Curran CS, Keely PJ. Breast tumor and stromal cell responses to TGF- $\beta$ and hypoxia in matrix deposition. Matrix Biol 2013;32:95-105.

15. Kim HS, Kim GY, Kim YW, Park YK, Song JY, Lim SJ, et al. Stromal CD 10 expression and relationship to the E-cadherin/beta-catenin complex in breast carcinoma. Histopathology 2010;56:708-19. 